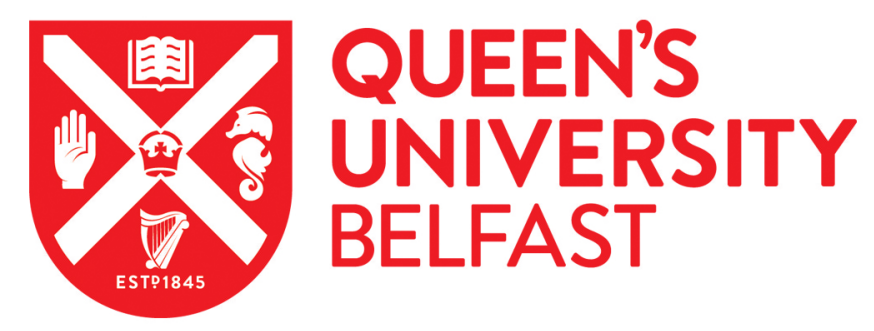

\title{
Freedom, republicanism, and workplace democracy
}

Breen, K. (2015). Freedom, republicanism, and workplace democracy. Critical Review of International Social and Political Philosophy, 18(4), 470-485. https://doi.org/10.1080/13698230.2015.1033857

\section{Published in:}

Critical Review of International Social and Political Philosophy

\section{Document Version:}

Peer reviewed version

\section{Queen's University Belfast - Research Portal:}

Link to publication record in Queen's University Belfast Research Portal

\section{Publisher rights}

(C) 2015 Taylor \& Francis

This is an Accepted Manuscript of an article published by Taylor \& Francis in Critical Review of International Social and Political Philosophy in 2015, available online: http://wwww.tandfonline.com/10.1080/13698230.2015.1033857

\section{General rights}

Copyright for the publications made accessible via the Queen's University Belfast Research Portal is retained by the author(s) and / or other copyright owners and it is a condition of accessing these publications that users recognise and abide by the legal requirements associated with these rights.

Take down policy

The Research Portal is Queen's institutional repository that provides access to Queen's research output. Every effort has been made to ensure that content in the Research Portal does not infringe any person's rights, or applicable UK laws. If you discover content in the Research Portal that you believe breaches copyright or violates any law, please contact openaccess@qub.ac.uk. 


\title{
Freedom, republicanism, and workplace democracy
}

\author{
Keith Breen*
}

School of Politics, International Studies and Philosophy, Queen's University, Belfast, Northern Ireland, UK

\begin{abstract}
This paper explores the republican case for worker voice in economic enterprises based on the ideal of freedom as non-domination, and assesses its merits relative to two influential arguments for workplace democratization grounded on freedom understood as autonomy and selfdetermination. Two claims are advanced. The first is that the republican case for worker voice avoids difficulties associated with these two arguments. The second, however, is that the ideal of non-domination is insufficient, that an adequate understanding and defence of workplace democracy will also have to make significant reference to freedom understood as autonomy.
\end{abstract}

Keywords: workplace democracy; freedom; autonomy; non-domination; workplace republicanism

\section{Introduction}

Over the past two decades republicanism has undergone a remarkable revival such that it now constitutes a major strand within contemporary political theory. With this revival, freedom and its institutional preconditions have once again become a central concern, leading to significant developments in our understanding of democracy, citizenship and the constitutional underpinnings of a free political order. The impact of republican thinking is not limited to these areas, however. Laborde and Maynor (2008, p. 21) were certainly correct in predicting 'republican political economy' would be a theme 'of growing importance and

\section{*Email: k.breen@qub.ac.uk}

Cite this article as: Breen, K. (2015) 'Freedom, republicanism, and workplace democracy’, Critical Review of International Social and Political Philosophy, 18 (4). DOI: 10.1080/13698230.2015.1033857. 
relevance in years to come'. Recent examples include republican justifications of basic income policies (Casassas and De Wispelaere 2012), property-owning democracy (White 2012) and green political economy (Barry 2012), to name but a few.

The concern of this study is republican interventions in an area of political economy having suffered comparative neglect - workplace democracy. Utilizing Philip Pettit’s negative ideal of freedom as non-domination, some republicans have argued for workplace democratization on the basis of workers' interests in countering arbitrary managerial interference. My goal is to assess the merits of this justification relative to earlier freedomcentred arguments for democratic firms that draw on a positive ideal of freedom understood in terms of self-determination and autonomy. My argument is twofold. I contend, first, that the republican non-domination case for worker voice avoids some of the pitfalls of earlier freedom-centred arguments for workplace democratization. However, my second claim is that the ideal of non-domination is insufficient on its own, that an adequate defence of workplace democracy will also have to incorporate, in substantial measure, positive freedom understood as self-determination. If this is true, then not only do republican defences of worker voice stand in need of revision, but also republican theory itself.

The discussion proceeds as follows. The first section sets out the 'psychologicalsupport' and 'parallel-case' justifications of democratic firms, focusing on the objections levelled against these. The second section explores, attending to the work of Nien-hê Hsieh, the republican case for workplace democracy - or, more accurately, 'workplace republicanism' - and clarifies the ways in which it overcomes the standard sceptical objections. In the third section, I offer a critique of Hsieh’s workplace republicanism based on wider criticisms of Pettit's understanding of socio-political freedom. The key points are that republican non-domination implicitly relies upon the ideal of autonomy, that an exclusive focus on non-domination leads to an impoverished understanding of democracy 
and that the problem of domination does not fully explain worker dissatisfaction with workplace management practices, which requires reference to positive freedom in order to be properly understood. I conclude by rebutting the claim that only freedom understood as nondomination should be the guiding ideal of institutional design.

\section{Two arguments for workplace democracy}

A democratic enterprise is one where workers have an effective right to participate in the collective governance of the organization and determine, by themselves or in conjunction with others, its internal regulation and future direction. This definition permits a wide variety of institutional forms, ranging from worker co-determination of enterprise policies with managers and capital owners to cooperativism, where workers both determine policy and own the means of production. It also permits significant variations in the form of democracy practiced in firms, with direct democracy at one end of the spectrum and indirect, representational democracy at the other.

The arguments of concern here have been employed to justify various types of democratic enterprise. The first appeals to the positive ideals of freedom as selfdetermination or autonomy, of deliberating over and rationally determining the course of our actions, and of freedom as self-realization, of actualizing and augmenting the capacities definitive of mature persons. Drawing on Mill (1972) and Pateman (1970), Joshua Cohen terms this justification the 'psychological-support argument'. The core idea is that the vibrancy of democracy at the political level depends upon 'forms of association "outside” the state, particularly in the economy, that strengthen the forms of thought, feeling, and selfunderstanding that give substance to democratic citizenship’ (Cohen 1989, p. 28). For Cohen, democratic citizenship has two psychological preconditions, namely, an ““active character”, citizens who believe they can determine their own futures and have the capacity to effect 
change, and a 'sense of the common good', the willingness to adjudicate in line with general interests. Because authoritarian enterprises grant decision-making primacy to managers and capital owners, they limit workers’ opportunities for practical deliberation as to the common good and for developing their capacities, 'thereby fostering passivity and a narrower basis of political judgement' that undermines democratic society as a whole (Cohen 1989, p. 29). The degree to which citizens act freely and responsibly in the political realm is, in short, materially conditioned by the level of freedom and responsibility permitted them in their everyday economic life.

The second argument, the 'parallel-case argument', justifies workplace democracy not in terms of its benefits for political democracy, but instead as a corollary of endorsing democratic equality and freedom as self-determination at the level of the state. 'If democracy is justified in governing the state', claims Dahl (1985, p.110), 'then it must also be justified in governing economic enterprises; and to say that it is not justified in governing economic enterprises is to imply that it is not justified in governing the state'. The concern here is defensible distributions of power, the basic premise being that the features of states which call for equitable distributions of power and therefore a right to self-determination are also features of most workplaces. The state, normatively viewed, is a cooperative association governed by general rules binding upon all members and endorsed in terms of their mutual advantage. Because citizens are members of a state, have the ability to judge the appropriateness of its general rules and, decisively, are subject to the coercive enforcement of these binding rules, they have a right to participate in its collective governance. But the same rings true of economic enterprises. Just like states, economic enterprises are cooperative associations governed by general rules applying to all members and endorsed in terms of their mutual advantage. And just like citizens, because workers are members of an economic enterprise, have the ability to judge the appropriateness of its general rules and, no less 
decisively, are subject to the coercive enforcement of these binding rules, they, too, ought to have the right to participate in its collective governance (Dahl 1985, pp. 56-62, 113-133; see also Cohen (1989, p. 27) and Walzer (1983, pp. 291-303)). Were we to believe otherwise, consistency would demand the rejection of democratic self-rule and an acceptance of authoritarianism outside the economic realm.

These freedom-centred arguments for workplace democratization are not without plausibility. This is particularly so with the psychological-support view of the workplace as a prime context for fostering the deliberative capacities and virtues definitive of autonomous citizenship. It might be objected that there are other spheres of life in which these virtues are learned, and that workplace authoritarianism poses no threat to our freedom as citizens given our opportunity to exercise our capacities elsewhere (Nozick 1974, p. 246). However, this neglects the distinctive role of work within many people’s lives. Unlike leisure pursuits or associational activities, which usually occupy us for limited periods, work typically takes up a large proportion of our time and is thus likely to have character-forming effects comparable to and probably in excess of other areas of life (O’Neill 2008). Indeed, compelling evidence exists in support of Adina Schwartz’s (1982, p. 637) contention that individuals within hierarchical workplaces performing jobs with little scope for discretion 'lead less autonomous lives on the whole'. In a celebrated study of US employees, for example, researchers discovered that the extent to which work activities required discretion had an appreciable impact on individuals’ psychological functioning, complex work enhancing their intellectual capacities over time and work lacking complexity decreasing these. Furthermore, and importantly, the effects of 'the structural imperatives' of jobs, in particular 'those conditions that facilitate or restrict the exercise of self-direction in work', were not limited to the workplace but affected 'workers' values, orientations to self and society and cognitive functioning primarily through a direct process of learning from the job and generalizing what 
has been learned to other realms of life’ (Kohn and Schooler 1983, p. 297; see also Hauser and Roan 2007). Accepting these wide-ranging consequences, it would be unreasonable to think working life has little bearing on our ability to act as self-determining citizens.

The appeal of the parallel-case argument rests on the close analogies drawn between states and enterprises. One key analogy, as indicated above, relates to the coercive power enjoyed respectively by state and managerial authorities. As Dahl (1985, p. 115) argues, members of economic enterprises, should they contravene managerial directives, are subject to sanctions often as 'severe' in their consequences as many of the sanctions levelled by state agencies against citizens. Indeed, the ultimate economic sanction, dismissal, which potentially condemns workers to sustained exclusion from economic activity altogether, is in some respects more severe than state sanctions, which ordinarily presume the continued membership of citizens in the state and its activities. A further key parallel concerns the comparative bindingness of state and enterprise decisions. The standard justification for instituting democracy in states but not in workplaces is the compulsory subjection of citizens to state rules in contrast to employees' supposed voluntary subjection to enterprise rules. However, the view that membership of economic enterprises is in truth voluntary stands belied by the realities faced by many workers (Dahl 1985, p. 114-115; 2001, pp. 251-252). Because of the gross inequalities characteristic of real-world capitalism, only a small minority can costlessly choose to exit a firm when they disagree with it decisions, just as only a minority, buoyed by affluence, can costlessly choose to leave their state. The majority of workers, in contrast, would appear as tightly bound to their enterprises as the majority of citizens are bound to their states.

For all their attractions, the psychological-support and parallel-case arguments are subject to objections rendering their plausibility prima facie at best. As regards the former, two criticisms are telling. First, the contention that workplace democracy enhances 
autonomous citizenship is ultimately an empirical claim dependent on contingencies which may vary significantly across cases. While some democratic firms may engender virtues conducive to a critical outlook and the common good (Elden 1981), others may lead to workerism - the narrow pursuit of worker self-interest - and a passive acceptance of wider societal prejudices (Greenberg 1981). Second, the quality of democracy at the political level might be sufficiently improved by workplace innovations falling far short of granting employees governance rights over enterprise policy. If a modicum of self-direction - more autonomous working teams on the floor level, say - helped foster a healthy sense of personal efficacy and collective responsibility among workers, then the psychological-support argument would require no more. Together these objections suggest advocates of workplace democracy should exercise caution in relying upon psychological-support arguments. This is so because the justification of workplace democratization provided by them is indirect and instrumental: according to these arguments, workplace democracy is justified only if it augments democracy at the political level. We may instead want more robust defences of democratic firms which focus directly on the working environment itself regardless of its benefits to political democracy.

As for the parallel-case argument, critics have challenged the close analogies drawn between states and firms. While managers enjoy coercive power, their power is substantially different from the power enjoyed by state agencies in terms of its scope and magnitude (Narveson 1992, p. 52). Regarding scope, though the reach of many economic enterprises is assuredly extensive, affecting people's lives in myriad and often injurious ways, the state remains singular in claiming the right to discretion over nearly all spheres of life, from the international to the familial. Regarding magnitude, the state's status as the sole association possessing legitimate resort to violence to enforce its decisions renders its power unique, at least in a de jure sense, in modern societies. To the extent that all this rings true, the analogy 
between states and firms would appear overdrawn and the parallel case for workplace democracy overstated. The parallel between states and firms in terms of the bindingness of their decisions has also been disputed. In market societies respecting the right of voluntary contract, employees remain formally free to exit firms should they desire (Arneson 1993, pp. 139-140), whereas the exit of citizens from a state depends upon other states permitting them residency. And even if, following Dahl, this formal right of exit is made hollow by workers' circumstances, the appropriate response to that injustice might not be workplace democracy in the first instance. Rather than seeking democratic voice for employees, which would not address the cause of their exploitation - socio-economic disadvantage - 'the proper cure' for the excessive cost of exiting firms would instead be 'a generous welfare state, or, more radically, redistribution of property’ (Mayer 2001, p. 243). If such measures can substantially lessen the cost of exiting firms, thus making membership in them voluntary in contrast to compulsory state membership, then the parallel case for workplace democratization would again appear moot.

\section{Non-domination and workplace republicanism}

The republican case for worker voice in firms promises a path beyond these objections. The basis of this case, however, is not freedom understood positively, but instead freedom conceived negatively as non-domination. For republicans, according to Pettit (1999, p. 165), freedom 'consists, not in the presence of self-mastery, and not in the absence of interference by others, but rather in the absence of mastery by others', that is, in the absence of domination understood as arbitrary interference. Unlike the non-arbitrary interference of a constitutionally-constrained system of law, which is publicly justified in accordance with general interests, domination entails interference by agents that is unaccompanied by justifications and fails to 'track the interests and ideas of the person suffering the 
interference' (Pettit 1997, p. 55). Those subject to this arbitrary power experience, akin to servants subject to their master's discretion, a worsening of their situation in three ways: in terms of restricted choice and options, in terms of ‘uncertainty' and an inability to securely plan for their futures and, most problematically, in terms of an 'asymmetry of status' and diminution of their sense of personal worth (Pettit 1997, pp. 82-90; 2001b, p. 351). A free social order is one where these evils are minimized and a symmetry of status between persons institutionally enshrined.

Republicans such as Nien-hê Hsieh have applied Pettit's theory of non-domination to the economic sphere in order to undercut workplace authoritarianism (Hsieh 2005, 2008a, 2008b; see also González-Ricoy 2014). Hsieh’s argument begins with the commonly accepted view that economic organization requires managerial decision-making rights or discretion in dealing with day-to-day business and unanticipated contingencies. These decision-making rights make possible the organizational flexibility necessary for the success of firms, yet they also grant managers extensive power to arbitrarily interfere in workers’ lives. Managerial power can be limited by legislation - safety standards, minimum wage rates, maximum weekly hours - and by contractual agreements and clear job descriptions, but it can never be eliminated by such measures, since no legislative device, contract or job description can account for all the contingencies which may arise or dispense with the need for discretion in responding to them. The 'challenge', therefore, is 'to protect workers against arbitrary instances of interference without ruling out [managerial] discretion altogether’ (Hsieh 2008a, p. 92).

Vulnerability to managerial domination takes numerous forms (Hsieh 2005, pp. 122123; 2008b, p. 64). Most obviously, managers enjoy discretion over the tasks workers perform and how they perform them. Examples include decisions concerning work pace, allocation of responsibilities, overtime, shift rotations and so forth, which can impact 
negatively on the experience of work itself and on life outside the workplace. Managers also possess decision-making rights over employees’ conditions of employment, including the working environment, remuneration, training opportunities and promotion criteria. Arbitrary interference at this level can lead to some workers being consistently disadvantaged in comparison to others, thus lessening their career prospects and hindering personal advancement. Finally, managers have the right to determine enterprise strategy, ranging, for instance, from the choice of product to be produced to the decision to relocate an enterprise, which can have far-reaching consequences for employees in subverting their professional identity or forcing a wedge between them and their communities. When employed arbitrarily, these kinds of managerial discretion severely restrict workers' choice of options, giving rise to uncertainty and limiting their ability to pursue their ends and life plans. Yet they also pose a threat, Hsieh (2005, p. 124-126) makes clear, drawing on Rawls, to the primary good of 'self-respect', the precondition of individuals being able to exercise their capacities and act independently at all. This is so because arbitrary managerial interference treats workers as objects, as if their interests and opinions did not count, thereby undermining, in their own eyes and the eyes of others, their status as free and equal persons.

It is for these reasons that Hsieh (2008a, p. 92) deems protection against managerial domination a 'basic right' comparable in importance to other fundamental rights and liberties. This right is partially satisfied by external legislative restrictions on workplace interference and opportunities for individual legal redress in courts. However, because these restrictions and opportunities cannot cover every eventuality and often involve considerable expense, an effective right of protection would require a regime in which workers are able 'to contest managerial decisions that result in severe forms of interference not only ex post, but also as part of the decision-making process internal to economic enterprises’ (Hsieh 2005, p. 136). Based on an interpretation of Pettit's republicanism as being primarily concerned with 
placing constraints on governmental authorities and ensuring the contestability of their decisions, Hsieh’s terms this regime ‘workplace republicanism’. Unlike workplace democracy typically understood, workplace republicanism does not entail employee control of enterprise policy, but instead their participation in decision-making processes in ways which guarantee that their voice will find register (Hsieh 2005, p. 138). The institutional mechanisms securing employee voice vary in accordance with the level of decision making. At the level of the performance of tasks, there might be internal 'adjudicative bodies' responsible for resolving individual disputes between managers and workers, whereas managerial decisions affecting collective conditions of employment and enterprise strategy would be better dealt with by work committees and by employee representation on boards of directors, as is the case in continental European systems of co-determination (Hsieh 2005, pp. 137, 139). Whatever their institutional guise, only republican arrangements of this sort can ensure the resilient defence of workers' basic interests.

Workplace republicanism enjoys distinct advantages over psychological-support and parallel-case arguments for workplace democracy. In contrast to psychological-support claims, its success does not depend on contingent causal relationships between the experience of working life and citizen virtues or on the instrumental benefits workplace democratization might have for the quality of democracy at the political level. Although these relationships and benefits may hold true, and would bolster the case for strong protections against managerial power if they did, they are neither required by workplace republicanism nor its focus. Instead, its focus is squarely on enterprise activities themselves, on the effects they have on employees qua employees, thus offering a direct, rather than indirect, justification for worker voice. And unlike parallel-case arguments, this justification does not presume close analogies between firms and states. The rationale for employee participation in enterprise decision-making processes is not that managers have power analogous in scope and 
magnitude to state agents. Rather, it is simply that they have dominating power, and this power frequently has intolerable consequences for people and should be curtailed regardless of any resemblances it may share with governmental power. Neither does workplace republicanism hinge upon tight parallels between the bindingness of state and enterprise rules and the claim that exit from them is similarly costly or constrained. Hsieh accepts that membership in firms can be voluntary and endorses the right of exit from economic enterprises as a basic right that can have salutary disciplinary effects on managerial behaviour. However, it is a mistake to think the right of exit an adequate protection against arbitrary interference (Hsieh 2005, pp. 127-131; González-Ricoy 2014, pp. 239-241). This is because there are significant costs associated with leaving enterprises - the loss of intra-firm personal capital, the expense of transitioning to new jobs, the risk of sustained unemployment and being stigmatized as unproductive - that even a substantive right of exit based on generous welfare provisions cannot address and which compel many to endure managerial domination. The only way to counter such compulsion is to permit contestation of management decisions at source.

\section{Autonomy, self-direction and organizational control}

In circumventing difficulties associated with psychological-support and parallel-case arguments, workplace republicanism provides an important vindication of employee voice. I want now to argue, however, that, while important, this vindication is insufficient, that the psychological-support and parallel-case justifications, despite their problematic paths, are correct in beginning with a positive ideal of freedom. I begin with two criticisms of Pettit's equation of socio-political freedom with non-domination, namely, that non-domination implicitly relies upon freedom conceived as autonomy, and that equating socio-political freedom with non-domination distorts our understanding of democracy. These criticisms, I 
believe, have even greater force against Hsieh’s workplace republicanism, suggesting that what is of significance for workers is not only protection against arbitrary managerial interference but also, and more fundamentally, the possibility of self-direction and organizational control.

The claim that republican non-domination trades upon the idea of autonomy and for that reason is insufficient has been forcefully made by Richard Dagger. One of Dagger's arguments relates to a basic republican policy prescription. Republicans, Pettit (1997, pp. 7677) maintains, should be concerned not only with eliminating those socio-political factors which 'compromise' freedom, that is, instances of domination, but also with addressing natural and social factors - ill health, physical disability, lack of education - which, while not involving arbitrary interference, nonetheless limit or 'condition' people’s ability to avail of their freedom. Dagger (2005, p. 186) believes Pettit right in desiring to counter both compromising and conditioning factors, yet his point is that if freedom is 'construed simply as non-domination' it would be fully served by tackling compromising or dominating factors alone. The inclusion of conditioning factors therefore suggests a veiled appeal to a richer notion of freedom, not just the absence of domination but of leading 'a self-governed life'. This suspicion is strengthened by consideration of Pettit's understanding of non-dominated personhood, which is strikingly redolent of autonomy and individual self-government (Dagger 2005, p. 187). 'To be a person', in Pettit's view, 'is to be a voice that cannot properly be ignored, a voice which speaks to issues raised in common with others and which speaks with a certain authority' (Pettit 1997, p. 91; 2001a, pp. 72, 140). To be a person, in other words, is to be worthy of respect, regarded as someone who can arrive at authoritative judgements which must be heeded and to whom justifications are owed in the making of collective decisions. This understanding clearly goes beyond an 'absence of mastery by others' to embrace the 'presence' of a specific sort of 'self-mastery', the ability of persons to 
independently deliberate over issues and to rationally determine their actions in conjunction with others (Forst 2013, pp. 162-163). Indeed, Pettit (1997, p. 81; 2001a, p. 71) concedes that he is in the end 'committed to a version of the autonomy ideal' in his conception of personal agency as 'discursive control', the dual capacity of individuals to reason and 'take part in discourse' and to influence and be influenced in turn by others’ opinions.

To enjoy the good of non-domination, in particular a resilient non-domination grounded on the capacity of persons to exercise discursive control, is therefore also to enjoy a good very much akin to self-determination. The tension generated by Pettit's endorsement of autonomy as essential to human agency and yet his reduction of freedom to non-domination in his republican political theory is noticeable. Similarly noticeable are the impoverishing effects the reduction of freedom to non-domination has on the ideal of democracy. For Pettit (1997, p. 30, emphasis added), democracy's importance rests simply on 'the fact that it is a means of furthering liberty' understood as non-domination. Democratic participation is valuable, not because of any 'independent attractions’ or intrinsic relation to freedom, and certainly not to freedom understood as self-determination, but rather as an instrument in protecting citizens from arbitrary interference (Pettit 1997, p. 8; 1999, p. 166). Democracy allows for such protection by permitting citizens to control collective decision making along two dimensions: the 'authorial' or electoral dimension, in which they act as indirect authors of public policy in selecting representatives who are attentive to their interests, and, more significant for Pettit generally, the 'editorial' or contestatory dimension, in which they challenge the decisions of these representatives via institutions such as courts, appeal bodies, ombudsmen and so forth (Pettit 2001a, pp. 159-167; 1999, p. 180). As Pettit's critics see it, the problem with this model of democracy is threefold. First, in holding that democratic participation has no intrinsic relation to freedom, this model neglects that it is only through participation that people can themselves come to understand particular policies or decisions as 
being in their interest and that 'being part of processes of self-legislation' is therefore, in an important way, 'constitutive’ of their status as free and equal citizens (Rostbøll 2008, pp. 56, 76). Second, emphasizing the contestatory over the authorial dimension and reducing the latter to a competition for votes, it 'moves attention away from the authorization and genesis of law' and discourages 'any inquiry into or experimentation with institutional forms that would enable a more participatory form of democracy’ (Rostbøll 2008, p. 55). Third, prizing non-domination over self-determination as the prime political value, it contents itself with an attenuated form of democratic control where the tracking of people’s interests is left to institutions - political parties, the judiciary, tribunals, expert commissions- presided over by professional elites and in which the de facto scope for democratic input is often slight (McCormick 2013, pp. 93-113). The overall result is a deflation of the democratic ideal.

If these criticisms and those of the previous paragraph hold, then they hold for Hsieh's workplace republicanism as well. As regards the issue of sufficiency, in prioritizing the good of 'self-respect' in his account of workplace republicanism, Hsieh appears necessarily committed, like Pettit, to a conception of personal agency requiring an institutional regime which simultaneously protects against arbitrary interference and ensures the ability of persons to act in a self-determining manner with others. In fact, close attention to his argument reveals self-direction and the enjoyment of discretion play a role in his theory as crucial as that played by non-domination. Hsieh’s starting point, we saw above, is the need for organizational discretion, and he concurs with Schwartz in thinking 'working relationships, and perhaps work itself, are more meaningful to the extent that they are openended and allow for flexibility' (Hsieh 2005, p. 136). However, Schwartz’s argument for discretion and flexibility in work rests explicitly on the notion of autonomy, and it is against that benchmark that she and others comprehend the injustices visited upon employees by workplace management practices (Schwartz 1982, pp. 635-639). Key to these practices, as 
clarified by Braverman (1974, pp. 77-83; see also Murphy 1993) in his critique of Taylorist forms of workplace management, are organizational innovations - the increasing emphasis on managerial over worker expertise; the division between managers' role of 'conception', of designing work processes, and workers' role of 'execution', of carrying these processes out; and managerial regulation of all aspects of standardized work systems - that profoundly transformed the modern work environment. The negative consequences of these innovations for workers can, on one level, be explained in terms of expanded managerial scope for arbitrary interference. Yet, on a more basic level, the threat they pose is not only domination in the sense understood by Pettit and Hsieh of suffering restricted choice, uncertainty and asymmetry of status, but also, and most cuttingly to individuals' self-worth, the denial to workers of what managers enjoy, which is precisely the opportunity both to act in a selfdetermining manner and to realize one’s capacities in doing so.

Employee dissatisfaction with managerial power stems as much from the circumscription of individual autonomy, and the gainsaying of personal dignity characterizing this, as it does from experiencing arbitrary interference. Although Hsieh certainly recognizes the desire of workers for self-direction in their jobs, his workplace republicanism is ill-suited to furthering this desire. This is so because when he speaks of the importance of discretion in economic enterprises, it is chiefly of the importance of discretion as exercised by managers, not by workers. The success of firms, he insists, hinges on managerial discretion, and it is a weakness of many justifications of workplace democracy that they pay 'insufficient attention to the need for managerial decision-making in large-scale economic enterprises’ (Hsieh 2005, pp. 116). Hence employees’ right not to organizational decision making per se, but instead to participate in decision-making procedures in order to contest the decisions made by managers. This view is beset with problems. One problem is the assumption that it is managers in the first instance who must decide enterprise policy. 
Against this, it is not unrealistic to think that most workers, given their immersion in work activities, can form opinions on enterprise policy at least as reasonable and knowledgeable as the opinions of either stockholders or managers. Moreover, where managerial decisionmaking priority is necessary, as in matters requiring advanced technical or logistical expertise, this is compatible with according employees the right to determine the domain and range of such decision-making priority (Dahl 1985, pp. 118-119). A more telling problem with Hsieh’s position, however, is the sanguine assumption that protection against domination satisfies the good of self-respect, when a clear import of this good is that all should contribute to the determination and control of collective futures. If we take this import seriously, then the 'challenge', pace Hsieh, is not only to insulate workers from the effects of managerial power, but to grant them a share in that power.

There are good grounds for doubting whether workplace republicanism as conceived by Hsieh can address this demand for an appropriate share in power. His understanding of the value of employee participation in enterprise decision making mirrors Pettit’s instrumental understanding of the value of citizen participation in the formation of public policy. For both, participation is valuable simply insofar as it promotes non-domination. Hsieh is therefore open to the criticisms levelled against Pettit's model of democracy, including that participation is to be valued intrinsically as being connected and giving expression to people’s freedom as self-governing beings. However, workplace republicanism diverges from Pettit's republican theory in two respects, rendering it vulnerable to further criticism. The first is that within Hsieh's workplace regime the authorial dimension of Pettit's republicanism, of ordinary citizens being the indirect authors of public policy, is not just underplayed, as is the case with Pettit, but in fact largely absent. Instead, the emphasis lies almost entirely on the contestatory dimension. One implication of this narrow appropriation of Pettit's theory is that authorship of enterprise policy, whether direct or indirect, should not 
to be thought a prerogative of employees, or at least not a prerogative they should share equally with management. The suggestion by Hsieh (2005, p. 138) that worker representation in his regime is 'analogous to the way in which citizens have representation' in parliament is unconvincing, since workers in this regime, unlike citizens in representative democracies, are not the ultimate ground and source of decision-making authority. A further implication of the emphasis on contestation, reinforced by the primacy accorded managerial discretion, is that employee participation in decision-making procedures under workplace republicanism amounts in essence to an internal retrospective right of redress, rather than a prospective right to shape organizational direction. Such redress may serve workers better than resorting to external adjudicative bodies such as labour courts, but it is no substitute for the power provided by actively setting agendas and determining enterprise policy.

The second respect in which Hsieh diverges from Pettit is of greater significance to the question of power. In Pettit’s democratic theory the privileging of non-domination over selfdetermination contributes to an attenuated form of popular control, but for Pettit, as for proponents of the psychological-support and parallel-case arguments for workplace democratization, control remains the central issue in matters of collective governance. Yet Hsieh (2008a, p. 93; 2008b, pp. 60) repeatedly makes clear that workplace republicanism is distinct from workplace democracy in granting workers a right of contestation but not necessarily organizational control, whether this be an exclusive right of control or control equal to that exercised by managers. This raises two questions over the attractiveness of workplace republicanism as a normative ideal. First, what sort of voice is ensured for workers if the right to contest managerial decisions does not necessarily entail some form of organizational control? Second, what are the incentives for management to respect workers' basic interests if the right of contestation is not accompanied by binding sanctions? It would appear that without significant control, worker voice would be a voice that must be heard, but 
not one which would have to be acted upon. It would also appear that without controlling sanctions, management would be tempted in periods of conflict to disregard the recommendations of internal adjudicative bodies and workplace committees. In such situations, employees would then have to rely on external institutions, whether courts and employment tribunals or unions and the threat of industrial action. Yet this undercuts the reason for endorsing workplace republicanism in the first place, which is that these external institutions are inadequate to the task of defending employees' basic interests (Hsieh 2005, pp. 135-137). In failing to insist upon the necessary connection between guaranteed voice and effective internal employee control, Hsieh thus comes close to destabilizing his project overall.

In point of fact, Hsieh’s preferred model of workplace governance - co-determination as practiced in various coordinated-market economies - does grant workers important degrees of organizational control (Addison 2009, pp. 15-23; Müller-Jentsch 1995, pp. 5859). In doing so, and despite Hsieh’s (2008b, p. 69) assertion to the contrary, it therefore approximates, albeit in modest ways, to the ideal of workplace democracy. The problem, ultimately, is that in distancing workplace republicanism from the idea of democratic control, Hsieh unduly constrains what is thought possible and desirable in the governance of firms and misappreciates the basis of employee protection against arbitrary interference, which is a measure of worker discretion and self-direction comparable to the measure of discretion and self-direction possessed by managers. But if control - the power and authority to determine collective decisions - is the core normative concern, then demands for workplace practices that respect the basic interests of all cannot be fulfilled by appeal to the concept of nondomination alone. Instead, they would seem to also require appeal to the richer notion of freedom and personal agency expressed by the positive ideal of living a self-determined life. 


\section{Conclusion}

I have argued here that workplace republicanism represents an advance on two influential freedom-centred arguments for institutionalizing worker voice and should thus be welcomed by those opposed to workplace authoritarianism. This advance consists in grounding the case for institutional reform not on the benefits it would have for political democracy or on close parallels between firms and states, but instead on the severe impact workplace organization can have on employees' lives. However, I have also argued that freedom understood as nondomination is not fully adequate for the defence of workplace democratization, given its implicit dependence on the positive ideal of freedom as autonomy, the inability of nondomination to properly account for worker dissatisfaction with managerial power and the reality that effective protection against arbitrary interference rests on the exercise of employee self-direction and organizational control. Together these points suggest the case for workplace democracy would be better served if freedom understood as self-determination, rather than non-domination, were deemed the primary value.

My arguments, of course, by no means amount to a dismissal either of non-domination as an ideal or of republicanism as a resource for criticizing authoritarian enterprises: my goal has simply been to show that self-determination must figure centrally in the case for workplace democratization. Nor have I offered here a comprehensive justification of workplace democracy on the basis of self-determination (see Gould 1988; Hyland 1995). I would like to conclude, nonetheless, by briefly rebutting the charge that self-determination is an inappropriate principle of institutional design. This charge is suggested by Pettit (1997, p. 82; 2001a, pp. 125-127; see also Pettit in this volume) when he claims the state should concern itself solely with the 'promotion of freedom as non-domination' and not 'embrace the richer ideal of promoting people’s personal autonomy'. He worries, like Berlin, that were the state to take this latter course, it would assume the perfectionist task of imposing a 
particular model of autonomous citizenship on people and thereby degenerate into 'an intrusive and oppressive entity’. A similar concern prompts Hsieh’s (2008a, p. 84) claim that 'thick' ideals of autonomy entail substantive visions of the good life which render them, in line with the principle of neutrality, 'unlikely candidates for a liberal egalitarian argument for workplace democracy'.

These worries regarding autonomy are misplaced. One reason for thinking so, most obviously, is that there is an important distinction to be made between 'thick' ideals of autonomy relying on substantive conceptions of the good life and those 'thin' ideals which focus on the general conditions of being able to lead a good life, whatever one's conception of the good might be. The ideal of personal autonomy appealed to here is concerned simply with the conditions of leading a self-governed life, and insofar as the resilient enjoyment of non-domination hinges on the satisfaction of these conditions, both Pettit and Hsieh would themselves seem committed to institutionally facilitating and promoting that ideal. As regards the potential for intrusiveness and oppression, there have been many instances of workplace institutional redesign - for example, Volvo’s far-reaching innovations in its Uddevalla automotive assembly plant (Breen 2012) - motivated explicitly by the goal of increasing worker autonomy and self-direction, and few have posed a threat to anyone's basic liberties or rights, indeed quite the reverse. And even if commitment to the ideal of autonomy does, in the end, presume a particular vision of autonomous personhood, this vision is no more offensively perfectionist than the republican vision of independent citizenship, of carrying ourselves with dignity and interacting with our peers - whether they be ordinary citizens, state officials or managers - with confidence, looking them in the eye without feeling the need to avert our gaze.

\section{Acknowledgements}


My thanks to Iseult Honohan, Cillian McBride, Fabian Schuppert and the members of the Queen’s University PPE Society for their comments on an earlier draft of this paper.

\section{Note on contributor}

Keith Breen lectures in political theory at Queen's University, Belfast. He has published on the philosophy of work and political ethics in a number of journals and is the author of Under Weber's shadow: modernity, subjectivity and politics in Habermas, Arendt and MacIntyre (Ashgate, 2012) and co-editor of After the nation? Critical reflections on nationalism and post-nationalism (Palgrave, 2010).

\section{References}

Addison, J., 2009. The economics of codetermination. Basingstoke: Palgrave Macmillan.

Arneson, R., 1993. Democratic rights at national and workplace levels. In: D. Copp, J. Hampton, and J. Roemer, eds. The idea of democracy. Cambridge: Cambridge University Press, 118-148.

Barry, J., 2012. The politics of actually existing unsustainability. Oxford: Oxford University Press.

Braverman, H., 1974. Labor and monopoly capital. New York: Monthly Review Press.

Breen, K., 2012. Production and productive reason. New Political Economy, 17 (5), 611-632.

Casassas, D. and De Wispelaere, J., 2012. The Alaska model: a republican perspective. In: K. Widerquist and M.W. Howard, eds. Alaska’s permanent fund dividend. New York: Palgrave Macmillan, 169-188.

Cohen, J., 1989. The economic basis of deliberative democracy. Social Philosophy and Policy, 6 (2), 25-50.

Dagger, R., 2005. Autonomy, domination, and the republican challenge to liberalism. In: J. Christman and J. Anderson, eds. Autonomy and the challenges to liberalism. Cambridge: Cambridge University Press, 177203.

Dahl, R., 1985. A preface to economic democracy. Berkeley: University of California Press.

Dahl, R. 2001. A right to workplace democracy? Response to Robert Meyer. The Review of Politics, 63 (2), 249-253.

Elden, J., 1981. Political efficacy at work. American Political Science Review, 75 (1), 43-58.

Forst, R., 2013. A Kantian republican conception of justice as nondomination. In: A. Niederberger and P. Schink, eds. Republican Democracy. Edinburgh: Edinburgh University Press, 154-168. 
González-Ricoy, I., 2014. The republican case for workplace democracy. Social Theory and Practice, 40 (2), 232-254.

Gould, C., 1988. Rethinking democracy. Cambridge: Cambridge University Press.

Greenberg, E., 1981. Industrial self-management and political attitudes. American Political Science Review, 75 (1), 29-42.

Hauser, R.M. and Roan, C.L., 2007. Work complexity and cognitive functioning at midlife. CDE working paper no. 2007-08. Available from: http://www.ssc.wisc.edu/cde/cdewp/2007-08.pdf [accessed 13 August 2013], $1-34$.

Hsieh, N., 2005. Rawlsian justice and workplace republicanism. Social Theory and Practice, 31 (1), 115-142.

Hsieh, N., 2008a. Justice in production. Journal of Political Philosophy, 16 (1), 72-100.

Hsieh, N., 2008b. Workplace democracy, workplace republicanism, and economic democracy. Revue de Philosophie Économique, 8 (2), 57-78.

Hyland, J., 1995. Democratic theory. Manchester: Manchester University Press.

Kohn, M. and Schooler, C., 1983. Work and personality. Norwood, NJ: Ablex Publishing.

Laborde, C. and Maynor, J., 2008. The republican contribution to contemporary political theory. In: C. Laborde and J. Maynor, eds. Republicanism and political theory. Oxford: Blackwell, 1-28.

McCormick, J., 2013. Republicanism and democracy. In: A. Niederberger and P. Schink, eds. Republican Democracy. Edinburgh: Edinburgh University Press, 89-127.

Mayer, R., 2001. Robert Dahl and the right to workplace democracy. The Review of Politics, 63 (2), 221-247.

Mill, J.S., 1972 [1861]. Considerations on representative government. London: J.M. Dent.

Müller-Jentsch, W., 1995. Germany: from collective voice to co-management. In: J. Rogers and W. Streeck, eds. Works councils. Chicago: University of Chicago Press, 53-78.

Murphy, J.B., 1993. The moral economy of labor. New Haven: Yale University Press.

Narveson, J., 1992. Democracy and economic rights. Social Philosophy and Policy, 9 (1), $29-61$.

Nozick, R., 1974. Anarchy, state, and utopia. New York: Basic Books.

O’Neill, M., 2008. Three Rawlsian routes towards economic democracy. Revue de Philosophie Économique, 8 (2), 29-55.

Pateman, C., 1970. Participation and democratic theory. Cambridge: Cambridge University Press. Pettit, P., 1997. Republicanism: a theory of freedom and government. Oxford: Oxford University Press. 
Pettit, P., 1999. Republican freedom and contestatory democratization. In: I. Shapiro and C. Hacker-Cordón, eds. Democracy’s value. Cambridge: Cambridge University Press, 163-190.

Pettit, P., 2001a. A theory of freedom. Cambridge: Polity Press.

Pettit, P., 2001b. Keeping republican freedom simple. Political Theory, 30 (3), 339-356.

Rostbøll. C., 2008. Deliberative freedom. Albany, NY: SUNY Press.

Schwartz, A., 1982. Meaningful work, Ethics, 92 (4), 634-646.

Walzer, M., 1983. Spheres of justice. New York: Basic Books.

White, S., 2012. Property-owning democracy and republican citizenship. In: M. O’Neill and T. Williamson, eds. Property-owning democracy. Oxford: Wiley-Blackwell, 129-146. 